\title{
Designing Magnetic Stirrer Hot Plate Using Contactless Infrared MLX90614 Temperature Sensor Based On PID Controller
}

\author{
Achmad Fiqhi Ibadillah ${ }^{1}$, Diana Rahmawati², Elfa Elismawati ${ }^{3}$, Riza Alfita ${ }^{4}$, Kunto Aji Wibisono ${ }^{5}$, Miftachul Ulum ${ }^{6}$ \\ Haryanto $^{7}$, Achmad Ubaidillah ${ }^{8}$, Rosida Vivin Nahari ${ }^{9}$ \\ Faculty of Engineering \\ University Of Trunojoyo Madura \\ Bangkalan, Indonesia \\ ${ }^{1}$ fiqhi.achmad@gmail.com, ${ }^{2}$ diana.rahmawati@trunojoyo.ac.id, ${ }^{3}$ elfaelis922@gmail.com, ${ }^{4}$ riza_alvita@trunojoyo.ac.id, \\ ${ }^{5}$ kunto.elektro@gmail.com, ${ }^{6}$ mif_ulum21@yahoo.com, ${ }^{7}$ haryanto_UTM@yahoo.com, ${ }^{8}$ ca_achmed@yahoo.com, \\ ${ }^{9}$ rosida_vn@yahoo.com
}

\begin{abstract}
Magnetic stirrer hotplate is a laboratory equipment which is used to heat and homogenize any chemical solvent. This equipment is usually used in chemical, microbiology and pharmacy laboratory. It is equipped with stirrer which is made up from magnetic stir bar. Our proposed magnetic stirrer hot plate controller uses ATMega16 microcontroller and equipped with temperature sensor MLX90614 to measure and monitor chemical solvent temperature and using DC (Direct Current) motor as a mover of stirrer. This tool is designed to have two type menus: automatic and manual. If using the automatic menu, the user only selects the mixing of the solution in the automatic menu. On the other hand when manual menu is selected temperature $\left(30-60^{\circ}\right.$ celcius), stirring velocity (400-1600 $\mathrm{rpm})$ and stirring time (1-30 minute) which can be seen at LCD display. The simulation result of PID (Proportional Integral Derivative) controller indicates stable condition when when $\mathrm{Kp}=\mathbf{0 , 0 1 1}, \mathrm{Ki}=$ 0.000001 , and $\mathrm{Kd}=\mathbf{0 . 0 0 0 0 1 2}$.
\end{abstract}

Keywords-hot plate, magnetic stirrer, infrared MLX90614, PID controller.

\section{INTRODUCTION}

The electronic technology development has take a role at industrial and medical technology. One of the positive impact in medical technology is the improvement of magnetic stirrer hot plate. It is used to heat chemical solvent or tissue which is usually used in microbiology, chemical and pharmacy laboratory. It is equipped with stirrer, made from magnetic stir bar, that homogenize and stabilize chemical solvent and keep the tissue temperature. It is equipped with temperature and stir velocity setting. To measure the temperature, it is still use analog thermometer.[1]

In our proposed method, we use contactless temperature sensor MLX90614 based on infrared to measure the temperature at the chemical solvent. We use magnetic bar stirrer that moved by DC motor to mix the chemical solvent. PID controller is used to control the DC motor speed according to the desired velocity set point based on constant value $\mathrm{Kp}, \mathrm{Ki}$, and $\mathrm{Kd}$. This device is equipped with manual and automatic mode. If automatic mode is selected then choose the desired solvent. If manual mode is selected then set the temperature (30-60o celcius), stirring velocity (400-1600 rpm) and stirring time (1-30 minute) which can be seen at LCD display.

\section{PREVIOUS RESEARCH}

Design hotplate is equipped with a heater driver to detect the temperature on the heater is placed on the plate. And it is equipped with ansensor infrared thermo that can measure the temperature of the heated solution without direct contact with the solution, making it easier for the laboratory to measure the temperature of the solution without using thermomether.

Isti'ah ira (2017)[2] in a study on "Design of Magnetic Stirrer Hotplate Based on Atmega8 Microcontroller". In this study the hotplate is equipped with a temperature control and rotational speed which is set by pressing thebutton up or down but for this determination it is not equipped with an automatic thermometer that can measure the temperature changes directly in the solution.

Irsyad Lalu Patria, Yudianingsih and Sri Lestari (2016)[3] in a study titled "Design Tools Magnetic Stirrer speed settings with the Sitter And the stirring time management". On the research for motor torque stirrer as sebaikknya using higher so that when the motor gets the load then the motor speed will be relatively stable.

Jecson Steven Daniel Zebua, Mas Sarwoko Suraatmadja, Ahmad Qurthobi (2016)[4] in a study entitled "Design of Digital Thermometers without Touch" this tool uses the MLX90614 sensor to read the best insurance temperature when reading the temperature at a distance of $15 \mathrm{~cm}$ in an open space.

In a "modul magnetic stirrer hotplate" that already exist must use a thermometer to measure the temperature of the heated solution. therefore surveyors laid out hotplate that is 
capable of measuring the temperature of the heated solution by using sensor MLX90614 infrared without direct contact with the solution, another advantage on the Tools menu, there is an automatic and a manual for mixing the solution.

\section{DESIGn Of The Control System}

Our research method is consist of hardware design and software design using CVAVR (Code Vision AVR) IDE

\section{A. Mechanical Design}

The mechanical design of the magnetic stirrer hot plate consists of several parts and the most important part is a heater. Heater is used to heat the chemical solvent. For more details, see Fig 1

From Fig 1 the magnetic stirrer hot plate mechanical design is shown which consists of the following parts:

1. Contactless infrared MLX90614 temperature sensor is used to detect the solvent temperature.

2. Temperature sensor holder.

3. Hot plate is made from stainless steel.

4. Heat reducer is made to maintain all of hot plate components from the heat.

5. LCD display is attached to show the setting and current value of parameters.

6. LED as system indicator.

7. Up button is used to increase the temperature, velocity and timer setting.

8. Set button is used to enter the setting mode.

9. Start button is used to start the device when all value has been set.

10. Reset button is used to reset all the setting or restart if the failure occur

11. On/Off button is used to activate and deactivate the device.

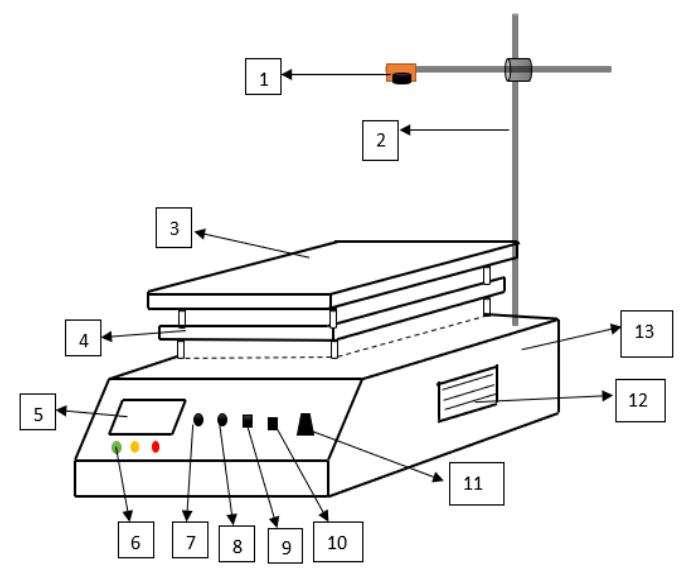

Fig. 1. Mechanical Design Of Magnetic Stirrer Hot Plate

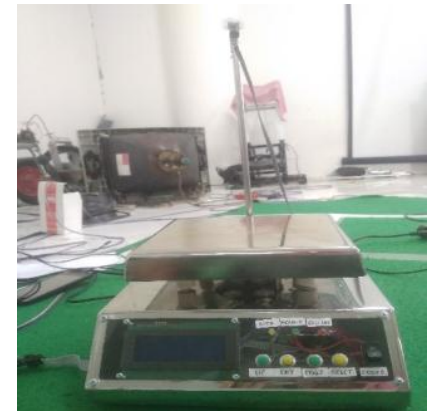

Fig. 2. Mechanical Design Implementation of Magnetic Stirrer Hot Plate

\section{B. Electrical Block Diagram}

In this research, a magnetic stirrer hot plate has been designed to heat and stir a solvent both manually and automatically. Figure 3 shows the block process diagram of the system based on the magnetic stirrer hot plate;

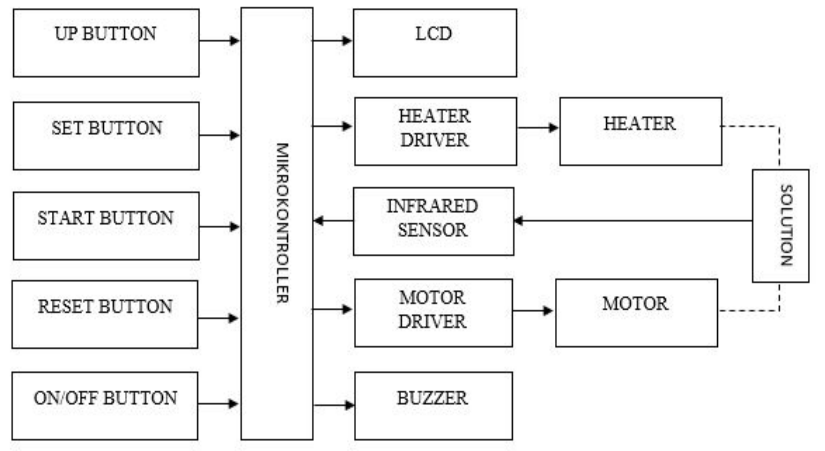

Fig. 3. Electrical Block Diagram Of Magnetic Stirrer Hot Plate

\section{Hardware Implementation}

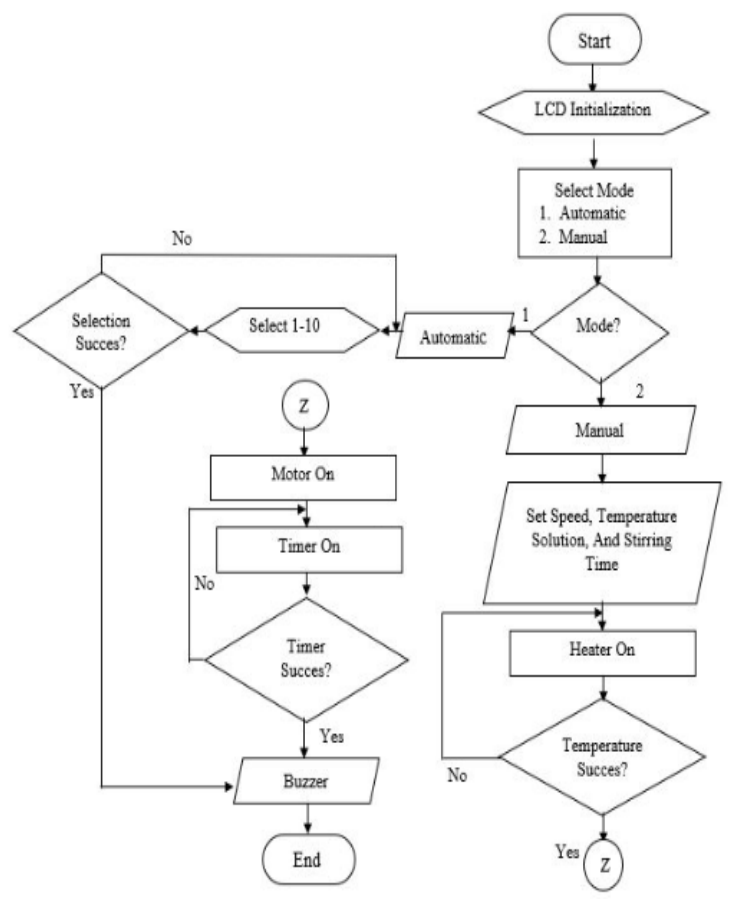

Fig. 4. System Flowchart 
From the figure above our magnetic stirrer hot plate has been equipped with contactless infrared sensor MLX90614 to detect temperature at chemical solvent. The microcontroller software process will be described below:

The first process is initialization that enables us to choose the mode both automatic and manual mode. If automatic mode is selected then choose the desired solvent, there are 10 samples of mixing solvent data, and push the start button then wait until finish. If manual mode is selected then set the temperature (30$60^{\circ}$ Celsius), stirring velocity (400-1600 rpm) and stirring time. If the user has one of the listed mixing solvent data then user can choose it and wait until finish. Contactless infrared temperature sensor MLX90614 will always detect the solvent temperature. If the temperature has reached the desired value then heater will be turned off and DC motor and timer will be activated until the timer setting has been reached. Our proposed method use PID controller to stabilize the velocity of DC motor and solvent temperature as determined at set point value.

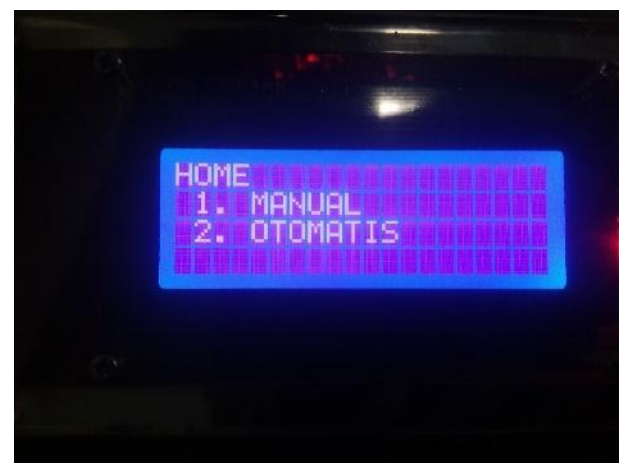

Fig. 5. System Mode

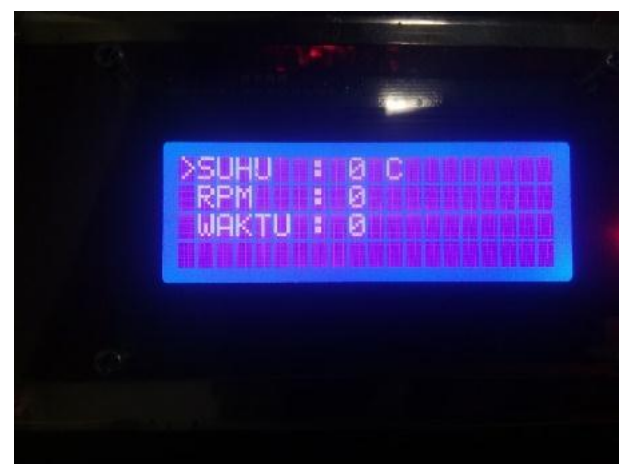

Fig. 6. Manual Mode

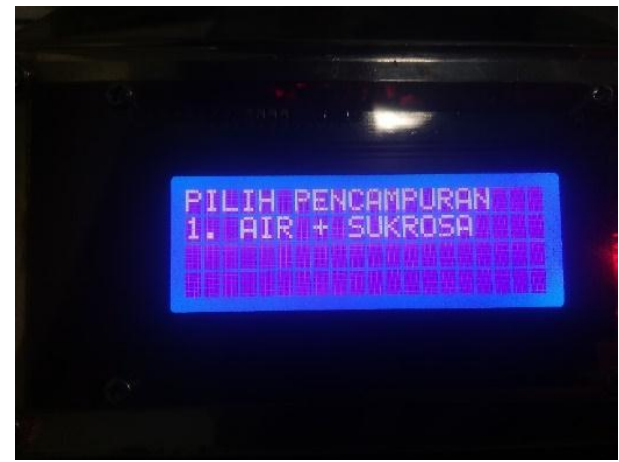

Fig. 7. Automatic Mode
TABLE I. CHEMICAL MIXING SOLVENT DATA (Source: Astari, Fauziah, dkk. 2014. "Laporan Resmi Praktikum Kimia Dasar I’. Samarinda: Universitas Mulawarman) [7]

\begin{tabular}{|c|c|c|c|c|c|}
\hline No. & & Solution & Temperature & Rpm & $\begin{array}{l}\text { Stirring } \\
\text { time }\end{array}$ \\
\hline 1. & $\begin{array}{l}\text { 1) } \\
\text { 2) } \\
\text { 3) }\end{array}$ & $\begin{array}{l}1 \text { liter cooking oil } \\
2.25 \text { grams Methol } \\
0.05 \text { gram } \\
\text { Sulfuric Acid }\end{array}$ & 65 & 400 & 2 minutes \\
\hline 2. & 1) & $\begin{array}{l}400 \mathrm{ml} \text { of water } \\
50 \text { grams of sugar }\end{array}$ & 30 & 400 & 3 minutes \\
\hline 3. & 1) & $\begin{array}{l}10 \mathrm{ml} \text { distilled water } \\
2 \text { gram sucrose }\end{array}$ & 45 & 400 & 2 minutes \\
\hline 4. & 1) & $\begin{array}{l}50 \mathrm{ml} \text { distilled water } \\
\mathrm{Ca}(\mathrm{OH})_{2} 1 \text { gram }\end{array}$ & 40 & 400 & 10 minutes \\
\hline 5. & $\begin{array}{l}\text { 1) } \\
\text { 2) } \\
\text { 3) }\end{array}$ & $\begin{array}{l}50 \text { grams of bulk } \\
\text { sugar } \\
\text { Iodine salt } 50 \text { grams } \\
400 \mathrm{ml} \text { tap water }\end{array}$ & 40 & 800 & 5 minutes \\
\hline 6. & $\begin{array}{l}\text { 2) } \\
\text { 3) }\end{array}$ & $\begin{array}{l}1 \text { liter of fried coconut } \\
\text { oil } \\
2.25 \text { grams of methol } \\
0.05 \text { grams of sulfuric } \\
\text { acid }\end{array}$ & 60 & 400 & 2 hours \\
\hline 7. & & $\begin{array}{l}\text { aquadest } 50 \mathrm{ml} \\
\text { sand }\end{array}$ & - & 800 & - \\
\hline 8. & 1) & $\begin{array}{l}\text { aquadest } 50 \mathrm{ml} \\
\text { chalk }\end{array}$ & - & 800 & - \\
\hline 9. & 1) & $\begin{array}{l}10 \mathrm{ml} \text { methanol } \\
\text { Tap water } 200 \mathrm{ml}\end{array}$ & 40 & 400 & 5 minutes \\
\hline 10. & $\begin{array}{l}\text { 1) } \\
\text { 3) } \\
\end{array}$ & $\begin{array}{l}10 \mathrm{ml} \text { ethanol } \\
50 \text { grams starch } \\
400 \mathrm{ml} \text { tap water }\end{array}$ & 40 & 800 & - \\
\hline
\end{tabular}

\section{PID CONTROL THEORY AND TUNNING ALGORITHM}

The development of PID control theories has already 60 years ago, PID control has been one of the control system design method of thelongest history. However, this method is still extensively used now. The structure of PID controller is simple; it is the most extensive control method to be used in industry so far. The PID controller is mainly to adjust an appropriate proportional gain $(\mathrm{Kp})$, integral gain $(\mathrm{Ki})$, and differential gain $(\mathrm{Kd})$ to achieve the optimal control performance. The PID controller system block diagram of this paper is shown in Figure1

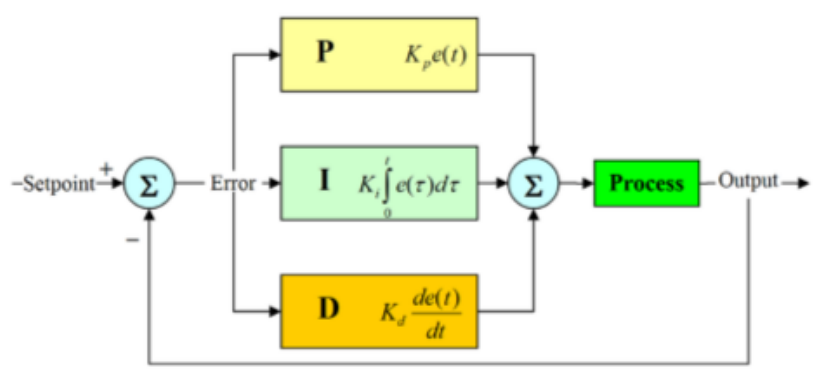

Fig. 8. PID Controller System Block Diagram.

The relationship between the input $\mathrm{e}(\mathrm{t})$ and output $\mathrm{u}(\mathrm{t})$ can be formulated in the following, 


$$
U(t)=K_{p} e(t)+K_{t} \int_{0}^{t} e(t) d t+K_{p} \frac{d e(t)}{d t}
$$

The transfer function is expressed as follows

$$
C(s)=K_{p}+\frac{K_{I}}{s}+K_{d} s=\frac{U(s)}{E(s)}
$$

The DC motor speed control using Close loop PID controller system block diagram is shown in Figure 2

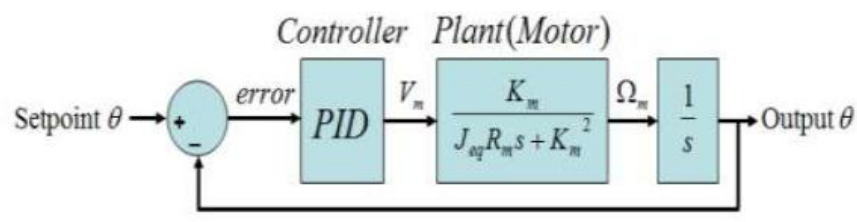

Fig. 9. Close Loop PID DC Motor Speed Control System Block Diagram

Ziegler Nichols Method (Closed-loop) is a type of continuous cycling method for controller tuning. The term continuous cycling refers to a continuous oscillation with constant amplitude and is based on the trial-and-error procedure of changing the proportional gain $(\mathrm{Kp})$. $(\mathrm{Kp})$ is reduced from larger value till the point at which the system goes to unstable state i.e. the point at which the continuous oscillations occurs. Thus the gain at which system starts oscillating is noted as ultimate gain $(\mathrm{Ku})$ and period of oscillations is ultimate time period $(\mathrm{Ku})$. It allows us to use the ultimate gain value, $(\mathrm{Ku})$, and the ultimate period of oscillation $(\mathrm{Pu})$ to calculate $(\mathrm{Kc})$. These two parameters, $(\mathrm{Ku})$ and $(\mathrm{Pu})$ are used to find the looptuning constants of the controller (P, PI, or PID) using the formula tabulated in Table 2.[5]

\section{TABLE II. ZIEGLER NICHOLS PARAMETERS}

\begin{tabular}{|c|c|c|c|}
\hline Controller & $\mathbf{K}_{\mathbf{P}}$ & $\mathbf{T}_{\mathbf{I}}$ & $\mathbf{T}_{\mathbf{D}}$ \\
\hline $\mathrm{P}$ & $0.5 \mathrm{~K}_{\mathrm{U}}$ & $\infty$ & 0 \\
\hline $\mathrm{PI}$ & $0.4 \mathrm{~K}_{\mathrm{U}}$ & $\frac{P_{U}}{1.2}$ & \\
\hline $\mathrm{PID}$ & $0.6 \mathrm{~K}_{\mathrm{U}}$ & $\frac{P_{U}}{2}$ & $\frac{P_{U}}{8}$ \\
\hline
\end{tabular}

The advantage of this method is that it is a proven online method and includes dynamics of whole process, which gives a more accurate picture of how the system is behaving. The disadvantage is that it up sets the process, uses trial and error method and has a very aggressive tuning. This closed-loop tuning method is limited to tuning processes that cannot run in an open-loop environment.

\section{Simulation And Analysis Of The System}

The experiment was carried out to determine the conditions and results of the magnetic stirrer hot plate. Testing was also conducted to determine the speed precision

\section{PID Tuning Experiment}

One of the motor speed controller method is by using PWM (Pulse Width Modulation), by changing duty cycle value so the motor speed will be changed as well [6]. This experiment purpose is to implement PID method in order to minimize the error of desired speed. In this experiment, the velocity is 400 rpm and the PID constants are tuned manually by using Zeiger and Nichols rule. In this rule, there are the value of $\mathrm{Kp}$ is set from 0 to a specific value until $\mathrm{Ku}=461.0$ and $\mathrm{Pu}=3$ as shown in the table below:

TABLE III. PID PARAMETERS VALUE WITH ZEIGER-NICHOLS METHOD

\begin{tabular}{|c|c|c|c|}
\hline $\begin{array}{c}\text { Controller } \\
\text { Type }\end{array}$ & $\mathbf{K}_{\mathbf{P}}$ & $\mathbf{T}_{\mathbf{I}}$ & $\mathbf{T}_{\mathbf{D}}$ \\
\hline $\mathrm{P}$ & $\begin{array}{c}0,5 \mathrm{Ku} \\
0,5.461=230,5\end{array}$ & $\infty$ & 0 \\
\hline $\mathrm{PI}$ & $\begin{array}{c}0,45 \mathrm{Ku} \\
0,45.461=207,45\end{array}$ & $0.5 \mathrm{Pu}=1,5$ & 0 \\
\hline $\mathrm{PID}$ & $\begin{array}{c}0,6 \mathrm{Ku} \\
0,6.461=276,6\end{array}$ & $\begin{array}{c}0,5 \mathrm{Pu} \\
0,5.3=1,5\end{array}$ & $\begin{array}{c}0,125 \mathrm{Pu} \\
0,125.3=0,375\end{array}$ \\
\hline
\end{tabular}

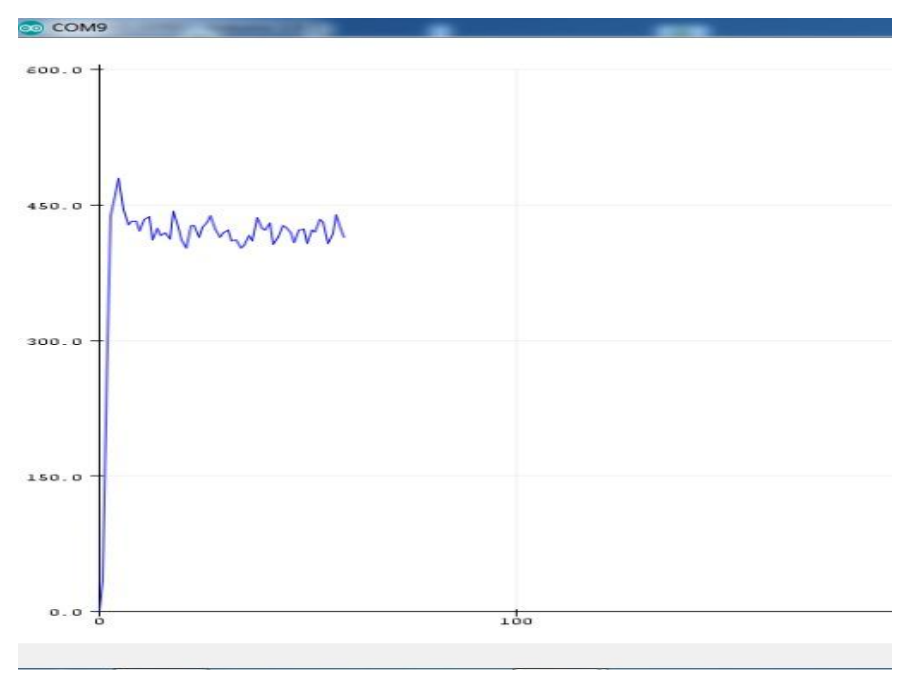

Fig. 10. PID Tuning with Zeiger-Nichols Method

\section{E. DC Motor Speed Measurement}

In this measurement, we use tachometer DT-2234C to measure the velocity of DC motor. The result is shown in the table below:

TABLE IV. VELOCITY EXPERIMENT

\begin{tabular}{|c|c|c|c|c|}
\hline \multirow{2}{*}{ No. } & \multicolumn{4}{|c|}{ Velocity (rpm) } \\
\cline { 2 - 5 } & $\mathbf{4 0 0}$ & $\mathbf{8 0 0}$ & $\mathbf{1 2 0 0}$ & $\mathbf{1 6 0 0}$ \\
\hline 1 & 407,7 & 798,6 & 1213,8 & 1594,0 \\
\hline 2 & 402,0 & 801,4 & 1200,0 & 1592,0 \\
\hline 3 & 403,8 & 802,8 & 1202,0 & 1595,0 \\
\hline 4 & 400,2 & 803,0 & 1200,0 & 1598,0 \\
\hline 5 & 408,0 & 802,0 & 1201,0 & 1601,0 \\
\hline Mean & 404.34 & 801.56 & 1203.36 & 1596,0 \\
\hline Deviation & 4.34 & 1.56 & 3.36 & 4 \\
\hline Error & $1.085 \%$ & $0.195 \%$ & $0.28 \%$ & $0.25 \%$ \\
\hline
\end{tabular}

Statistical analysis is shown below:

$$
\begin{aligned}
& \text { 1. } \operatorname{Mean}(X)=\frac{X n}{n} \\
& X=\frac{407,7+402+403,8+400,2+408,0}{5} \\
& X=404,34
\end{aligned}
$$


2. Deviation $=$ setting data $-\bar{X}$

Deviation $=400-404,34$

Deviation $=4,34$

3. $\%$ error $=\frac{\text { setting data }-\bar{X}}{\text { setting data }} \times 100 \%$

$$
\% \text { error }=\frac{4,34}{400} \times 100 \%
$$

$\%$ error $=1,085 \%$

From the experiment, we got error $=1.085 \%$ for $400 \mathrm{rpm}$, error $=0.195 \%$ for $800 \mathrm{rpm}$, error $=0.28 \%$ for $1200 \mathrm{rpm}$, and error $=0.25 \%$ for $1600 \mathrm{rpm}$. The highest error is at $400 \mathrm{rpm}$ and the lowest one is $800 \mathrm{rpm}$

\section{F. Temperature Measurement}

In this measurement, we use digital thermometer TP101 and put temperature sensor MLX90614 at $3 \mathrm{~cm}$ above the glass. The result is shown in the table below:

TABLE V. TEMPERATURE EXPERIMENT

\begin{tabular}{|c|c|c|c|c|}
\hline \multirow{2}{*}{ No. } & \multicolumn{4}{|c|}{ Temperature (C) } \\
\cline { 2 - 5 } & $\mathbf{3 0}$ & $\mathbf{4 0}$ & $\mathbf{5 0}$ & $\mathbf{6 0}$ \\
\hline 1 & 30.1 & 40.5 & 50.1 & 60.6 \\
\hline 2 & 29.8 & 40.1 & 50.1 & 60.2 \\
\hline 3 & 29.9 & 39.9 & 50.2 & 60.5 \\
\hline 4 & 30.0 & 39.7 & 50.5 & 59.2 \\
\hline 5 & 30.6 & 39.6 & 50.2 & 60.5 \\
\hline Mean & 29.40 & 39.96 & 50.22 & 60.4 \\
\hline Deviation & 0.6 & 0.04 & 0.22 & 0.4 \\
\hline Error & $2 \%$ & $0.1 \%$ & $0.44 \%$ & $1 \%$ \\
\hline
\end{tabular}

Statistical analysis is shown below:

1. $\operatorname{Mean}(X)=\frac{X n}{n}$

$$
X=\frac{30,1+29,8+29,9+30,0+30,6}{X \stackrel{n}{=} 29,40}
$$

2. Deviation $=$ Setting data $-\bar{X}$

Deviation $=30-29.40$

Deviation $=0,6$

3. $\%$ error $=\frac{\text { setting data }-\bar{X}}{\text { setting data }} \times 100 \%$

$$
\% \text { error }=\frac{0,6}{30} \times 100 \%
$$$$
\% \text { error }=2 \%
$$

In this experiment, we got error $=2 \%$ for $30^{\circ} \mathrm{C}$, error $=$ $0.1 \%$ for $40^{\circ} \mathrm{C}$, error $=0.44 \%$ for $50^{\circ} \mathrm{C}$, and error $=1 \%$ for 60

${ }^{\circ} \mathrm{C}$. The highest error is at $30^{\circ} \mathrm{C}$ and the lowest one is $40^{\circ} \mathrm{C}$

\section{CONCLUSION}

Based on the results of the design, implementation and testing of the system that has been made, the following conclusions can be drawn:

1. From trial, the value $\mathrm{Kp}=0,03, \mathrm{Ki}=0.000001$, and $\mathrm{Kd}=$ 0.000012 and motor rpm is more stable even though there is still error $1,085 \%$.

2. Error tolerance testing ranges between $2 \%-5 \%$, from the results of the rpm test,it is obtained the highest error $1,085 \%$ that is still categorized as good because it is still in the range of tolerance.
3. During temperature testing, it is obtained the highest error at a temperature 30 with the error $2 \%$ which is in good categories.

\section{REFERENCES}

[1]. Riki, "pengertian dan fungsi dari hotplate," [online], Available: http://www.alatlabor.com/article/detail/221/pengertian-dan-fungsi-darihotplate. [Accessed at 5-Sept-2018].

[2]. I. Isti'anah, Rancang Bangun Hot Plate Magnetic Stirrer Berbasis Mikrokontroler Atmega8, Yogyakarta: Universitas Muhammadiyah Yogyakarta, 2017.

[3]. S. Jecson, D. Zebua, M. S. Suraatmadja, A. Qurthobi, Perancangan Termometer Digital Tanpa Sentuhan, Jakarta: Universitas Telkom, 2016.

[4]. L. P. Irsyad, S. L. Yudianingsih, Perancangan Alat Magnetic Stirrer Dengan Pengaturan Kecepatan Pengaduk Dan Pengaturan Waktu Pengadukan, Yogyakarta: Universitas Respati Yogyakarta, 2016.

[5]. C. Arguta, S. Rubiyanti, E. Sulistyo, Kontrol Kecepatan Motor Dc Dengan Kontrol Pid Berbasis Mikrokontroller Atmega 8535, Bangka: Politeknik Manufaktur Negeri Bangka Belitung, 2017.

[6]. R. C. Brian, The Design of PID Controllers using Ziegler Nichols Tuning, 2008.

[7]. F. Astari, dkk, Laporan Resmi Praktikum Kimia Dasar 1, Samarinda: Universitas Mulawarman, 2014 